\title{
Effects of ad libitum milk replacer feeding and butyrate supplementation on behavior, immune status, and health of Holstein calves in the postnatal period
}

\author{
C. Gerbert, ${ }^{*}$ D. Frieten,† C. Koch, ${ }^{* 1}$ G. Dusel,† K. Eder,‡ T. Stefaniak,§ J. Bajzert,§ P. Jawor,§ A. Tuchscherer,\# \\ and H. M. Hammon $\|^{1}$ \\ *Educational and Research Centre for Animal Husbandry, Hofgut Neumuehle, 67728 Münchweiler an der Alsenz, Germany \\ †Department of Life Sciences and Engineering, University of Applied Sciences Bingen, 55411 Bingen am Rhein, Germany \\ łlnstitute of Animal Nutrition and Nutrition Physiology, Justus-Liebig-University Giessen, 35392 Giessen, Germany \\ $\S D e p a r t m e n t$ of Immunology, Pathophysiology and Veterinary Preventive Medicine, Faculty of Veterinary Medicine, \\ Wroclaw University of Environmental and Life Sciences, 50-375 Wroclaw, Poland \\ \#Institute of Genetics and Biometry, and \\ IIInstitute of Nutritional Physiology “Oskar Kellner," Leibniz Institute for Farm Animal Biology (FBN), 18196 Dummerstorf, Germany
}

\begin{abstract}
Animal welfare in dairy calf husbandry depends on calf rearing and is probably improved by intensive milk feeding programs. In addition, butyrate supplementation in milk replacer (MR) stimulates postnatal growth and may affect the immune system in calves. We have investigated the combined effects of ad libitum MR feeding and butyrate supplementation on feeding behavior, health, and the immune responses in calves. Holstein calves $(\mathrm{n}=64)$ were examined from birth until wk 11 of age. Calves received MR either ad libitum (Adl) or restrictively (Res) with (AdlB+, ResB+) or without (AdlB-, ResB-) $0.24 \%$ butyrate supplementation starting on d 4. From wk 9 to 10, all calves were gradually weaned and were fed $2 \mathrm{~L} / \mathrm{d}$ until the end of the trial. Concentrate, hay, and water were freely available. Calves were housed in straw-bedded group pens with automatic MR feeders, where feed intake and feeding behavior were documented. Blood was drawn on $\mathrm{d} 1$ before the first colostrum intake; on $\mathrm{d} 2,4$, and 7 ; and weekly thereafter until the end of the study to measure plasma concentrations of total protein, albumin, the immunoglobulins $\operatorname{IgG}_{1}, \operatorname{IgG}_{2}$, and $\operatorname{IgM}$, and the acute phase proteins fibrinogen, serum amyloid $\mathrm{A}$, and haptoglobin. Liver samples were taken on d 50 and 80 to determine gene expression related to acute phase proteins. Body temperature was measured daily for the first $3 \mathrm{wk}$, and clinical traits were scored daily. Ad libitum MR feeding resulted in greater MR intake, greater MR intake per meal, slower sucking rate, and greater
\end{abstract}

\footnotetext{
Received February 5, 2018.

Accepted April 9, 2018.

${ }^{1}$ Corresponding authors: C.Koch@neumuehle.bv-pfalz.de and hammon@fbn-dummerstorf.de
}

body weight, but in a lower number of unrewarded visits and lower concentrate intake when compared with Res. Butyrate reduced the sucking rate but increased MR intake per meal. Immunoglobulins in the blood plasma increased after colostrum intake in all calves, with only minor differences among groups throughout the study. Plasma fibrinogen and serum amyloid A increased in the first week of life in all calves, and fibrinogen was greater in Res than in Adl on d 21, 49, and 63. Hepatic gene expression of fibrinogen on d 80 was greater in Adl than in Res. Gene expression of $S A A 2$ was greater on d 50 in Adl than in Res and on d 80 was greater in ResB + than in ResB-. Body temperature was greater in Adl than in Res during the first 2 wk, but neither MR feeding nor butyrate affected the health status. An improved animal welfare in Adl calves is supported by fewer signs of hunger, but intensive milk feeding and butyrate did not affect the health and immune status of the calves in a consistent manner.

Key words: calf, ad libitum feeding behavior, butyrate, health, immunoglobulin passive transfer

\section{INTRODUCTION}

Intensive milk feeding programs may contribute to advanced animal welfare of preweaning calves (von Keyserlingk et al., 2009; Miller-Cushon and DeVries, 2015), indicated by fewer signs of hunger (Hammon et al., 2002; de Paula Vieira et al., 2008; Borderas et al., 2009), greater vitality (de Passillé et al., 2016), and a more robust immune response (Khan et al., 2011; Ollivett et al., 2012; Obeidat et al., 2013) during the postnatal period. Recent findings from a holistic whole transcriptome analysis in a subset of restricted and ad libitum milk replacer (MR)-fed calves of the present study indicate a consistently lower activation of the je- 
junal mucosal immune system, indicated by a reduction of pathways involved in activation of macrophages and attraction and priming of $\mathrm{T}$ cells, in restricted MR-fed calves (Hammon et al., 2018). The milk feeding strategy during the preweaning period may also affect the postweaning immune response in dairy calves (Ballou, 2012; Ballou et al., 2015), pointing to the importance of calf management during early life for long-term health and welfare (Hulbert and Moisa, 2016). However, intensive MR feeding programs are very heterogeneous in their implementation, and some of them revealed negative effects on calf health, especially on fecal scores (Quigley et al., 2006, 2017).

High mortality and morbidity rates still occur in dairy calf rearing. The nutritional management of the preweaning calf is one issue that should be questioned with respect to health and farm animal welfare aspects (von Keyserlingk et al., 2009; Mee, 2013; FAWC, 2015). In addition to adequate colostrum management, growing evidence suggests that insufficient milk or MR supply during the first weeks of postnatal life compromises the maturation and health of dairy calves (Khan et al., 2011, 2016; FAWC, 2015). However, the discussion on the extent of the milk feeding level is still ongoing. Restricted milk feeding to less than $6 \mathrm{~L} / \mathrm{d}$ in 2 daily portions by bucket is still common (Hill et al., 2016) but leads to abnormal behavior, such as cross-sucking and subsequent health problems (Hammon et al., 2002; Khan et al., 2011; Mahmoud et al., 2016). The opposite is true in beef production, where calves are allowed to drink colostrum and milk ad libitum and are not forced to drink the daily ration in 2 meals (Egli and Blum, 1998; Schiessler et al., 2002; Miller-Cushon and DeVries, 2015). The use of automatic MR feeders allows the intake of more milk or MR than commonly fed, and the daily ration can be divided into several meals to avoid an overload of the abomasum (Hammon et al., 2002; Maccari et al., 2015; Schäff et al., 2016). This feeding method is close to the natural situation (except regulation of feed intake by the mother), avoids hunger, discomfort, and metabolic stress, and therefore may provide improved health in preweaning calves. Calves fed MR ad libitum by an automatic feeder gained more BW and had an elevated IGF-I status (Schäff et al., 2016; Frieten et al., 2017, 2018) that reflects improved body growth but may also stimulate the immune system in calves (Clark, 1997; Khan et al., 2011).

Besides intensive milk feeding, butyrate supplementation of the MR may further improve the development and immune response of calves, especially in artificial rearing systems, because of its well-known effects on maturation of the gastrointestinal tract, growth performance, immune response, and health (Guilloteau et al.,
2010; Canani et al., 2011; Jiang et al., 2015). Therefore, we combined the positive effects of intensive MR feeding and butyrate supplementation to study the effects of both treatments on calf health as well as the immune and inflammatory status during the preweaning period. We hypothesized that animal welfare improves with fewer signs of hunger and that health and immune status improve when calves are fed MR ad libitum for the first $8 \mathrm{wk}$ of age and when the MR is supplemented with butyrate.

\section{MATERIALS AND METHODS}

The present study was conducted at the Educational and Research Centre for Animal Husbandry, Hofgut Neumuehle, Germany, following the guidelines of the German Law for Animal Welfare by permission of the corresponding authority (G 13-20-068; Landesuntersuchungsamt Rheinland-Pfalz, Koblenz, Germany).

\section{Animals, Housing, and Diets}

Sixty-four German Holstein calves (32 females and 32 males) were studied from birth until d $80 \pm 2$ (mean \pm SD) of life. Birth was monitored by the birth alarm system iVet (Papenburg, Germany) to ensure that calves did not suck at the udder before beginning the study. Only healthy calves with complication-free births and a birth weight between 35 and $55 \mathrm{~kg}$ were included in the study, as described recently (Frieten et al., 2017). Within $2 \mathrm{~h}$ after birth, calves were fed $2.5 \pm 0.09 \mathrm{~kg}$ (mean $\pm \mathrm{SD}$ ) colostrum from their dams with a calf feeder (speedy feeder, Shoof International Ltd., Cambridge, New Zealand). Five calves were fed the same amount of collected colostrum (pool colostrum of the farm), which was stored at $-20^{\circ} \mathrm{C}$, because the colostrum from their dams was not available. All calves received $10 \mathrm{~mL}$ of an iron suspension per os $\left(115 \mathrm{mg}\right.$ of $\mathrm{Fe}^{3+} / \mathrm{mL}$, Sinta fero-bac, Sinta GmbH, Schwarzenborn, Germany). Their navels were disinfected with an iodine lotion (Albrecht GmbH, Aulendorf, Germany) to protect against bacterial infections. Calves were weighed with an electronic scale (Tru-Test Ltd., Auckland, New Zealand) after the first meal. For birth weight determination, colostrum intake was subtracted. Calves were brought 2 to $3 \mathrm{~h}$ after birth into straw-bedded single hutches (Flixbox, Mayer Maschinenbaugesellschaft $\mathrm{mbH}$, Tittmoning, Germany) for the first $10 \pm 3$ (mean $\pm \mathrm{SD}$ ) days of life. Calves were allocated to 1 of 4 treatment groups and were blocked by birth weight, sex, and the number of lactations of their respective dams. Acidified transition milk from their dams (2 mL of Schaumacid/L of milk, H. W. Schaumann GmbH, Pinneberg, Germany) was 
offered for the next 5 meals $(2.5 \mathrm{~d})$ in amounts of 3 $\mathrm{kg} / \mathrm{meal}($ Res; $\mathrm{n}=32$ ) or ad libitum (Adl; $\mathrm{n}=32$ ). Colostrum, milk, and residues were weighed with an electronic scale (Sartorius AG, Göttingen, Germany). From meal 7 (d 4) onwards, calves were fed MR (12.5\% solids, Trouw Nutrition Deutschland GmbH, Burgheim, Germany) with or without butyrate supplementation ( $0.24 \%$ butyrate of DM in MR, $0.33 \%$ calcium-sodiumbutyrate of DM, Benelux GmbH, Amel, Belgium) in amounts of either $6 \mathrm{~L} / \mathrm{d}$ (ResB+; ResB-; $\mathrm{n}=16$, respectively) or ad libitum (maximum $25 \mathrm{~L} / \mathrm{d}$; AdlB+; AdlB-; $\mathrm{n}=16$, respectively). The butyrate supplement contained $77.1 \%$ butyrate, $9.8 \%$ sodium, $7.0 \%$ calcium, $0.7 \%$ palm oil, and $2.5 \%$ water.

In hutches, calves were fed via bucket with an artificial teat twice daily, and buckets for Adl calves were reloaded if necessary to ensure that buckets were never without milk. Buckets were cleaned twice daily and unconsumed milk was discarded. After the first period in the hutches, calves were transported into an open bipartite straw-bedded stable with automatic feeding systems for MR and concentrate, respectively (FörsterTechnik GmbH, Engen, Germany). For each side of the barn, one automatic MR feeder with 2 drinking stations was available for calves younger than $3 \mathrm{wk}$ of age and calves 4 wk of age and older to ensure that young calves had sufficient access to the MR feeding station. When calves did not drink by themselves at their first day of access to the automatic feeder, some help was provided by the staff $2 \mathrm{~h}$ after registration at the feeder. To prevent overfeeding, the volume per meal was limited for all calves (Res, $2 \mathrm{~L}$ per meal; Adl, $5 \mathrm{~L}$ per meal). As shown in a recent study, young calves are able to drink $5 \mathrm{~L}$ of milk per meal without reflux of milk into the rumen (Ellingsen et al., 2016). A subsequent time interval without access to the automatic feeder was established (Res, $2 \mathrm{~h}$; Adl, $30 \mathrm{~min}$ ) to make sure that calves will not occupy the automatic MR feeder for a couple of minutes without drinking. Previous studies showed less occupation of the automatic feeder when calves were allowed to drink MR ad libitum (Hammon et al., 2002). Ingredients and composition of MR and concentrate (Kälberkraft extra, Raiffeisen Waren-Zentrale Rhein-Main eG, Köln, Germany) are published in a paper from Frieten et al. (2017) and are presented in Supplemental Table S1 (https://doi.org/ 10.3168/jds.2018-14542). Hay, concentrate, and water were offered freely in each group. Calves received a full amount of their feeding regimen until d 56 of life. Then, MR was linearly decreased until d 70 . Thereafter, all calves received $2 \mathrm{~L} / \mathrm{d}$ until the end of the study. All calves were dehorned after anesthesia and sedation at 4 wk of age by cauterization following a strictly defined protocol with antiphlogistic and analgesic treatment.

\section{Health and Behavior}

Health parameters in calves were observed during the entire trial period. Feces (score $1=$ well formed; score 2 = pasty, but formed; score $3=$ smooth, but persist on bedding; score $4=$ watery, runs through bedding), navel (score $1=$ normal; score $2=$ edematous, as thick as a finger; score 3 = inflammatory, discharge of pus), and respiratory tract (score $1=$ healthy; score $2=$ runny nose; score 3 = heavy breathing, cough) were scored. Score classification was based on the scoring system from the School of Veterinary Medicine (2017), University of Wisconsin-Madison. Body temperature was measured daily using a rectal thermometer (VT1831, Microlife AG Swiss Corporation, Widnau, Switzerland) for the first 3 wk of life. After that, temperature was only measured when there was a difference from normal score or in cases of abnormal behavior, less feed intake, and symptoms of diseases. Fever was defined as a core body temperature over $39.5^{\circ} \mathrm{C}$. The half of the year (score $1=$ spring and summer; score $2=$ autumn and winter) was considered in the health protocol to realize possible coherences between health status and seasons. Among calves, 24 calves were born in spring or summer and 40 calves were born in autumn and winter.

In cases of illness, calves were immediately treated by a veterinarian. Electrolytes (Bewilyt Elektrolyttränke, Bewital GmbH \& Co. KG, Südlohn-Oeding, Germany) and essence of spruce (Stullmisan vet. Pulver, MSD Tiergesundheit, Intervet Deutschland GmbH, Unterschleißheim, Germany) were administered when feces were scored 3 or 4 until it became a score of 2 to 1 . In cases of illness, the intensity, duration, and treatment of the disease were documented. Because of the increased appearance of respiratory diseases in autumn 2014 at the Educational and Research Centre for Animal Husbandry, Hofgut Neumühle, calves were vaccinated against bovine respiratory syncytial virus and parainfluenza type-3 virus (Rispoval RS+PI3 IntraNasal, Zoetis Belgium SA, Ottignies-Louvain-la-Neuve, Belgium) from December 2014 to March 2015 after d 7 of life.

Data about sucking behavior and feed intake were gathered by the PC-program Kalb Manager WIN (Förster-Technik GmbH, Engen, Germany) that was connected to the automatic MR feeder. The number of total visits, rewarded and unrewarded visits per day, amount of liquid feed intake per meal and day, and sucking rate per meal for each calf were provided by the software.

\section{Milk, Blood, and Liver Sampling and Analyses}

Before colostrum feeding, $50 \mathrm{~mL}$ of the first colostrum from each dam was stored at $-20^{\circ} \mathrm{C}$ in single 
tubes (Cellstar centrifuge tubes, Greiner Bio-One GmbH, Frickenhausen, Germany). Colostrum quality was determined by 2 different digital refractometers (Wine refractometer, HI96811, Hanna instruments Inc., Woonsocket, RI, and Pocket Refraktometer, Atago USA Inc., Bellevue, WA), and the concentrations of $\operatorname{IgG}_{1}, \operatorname{IgG}_{2}$, and IgM were determined. Immunoglobulin $\mathrm{G}_{1}, \operatorname{IgG}_{2}$, and IgM were determined by ELISA (no. E10-116, E10-101, E10-117, Bethyl Laboratories Inc., Montgomery, TX). Intra-plate CV (\%) for $\mathrm{IgG}_{1}, \mathrm{IgG}_{2}$, and $\operatorname{IgM}$ was $3.0,1.9$, and $2.1 \%$, respectively. Interplate CV (\%) for $\operatorname{IgG}_{1}, \operatorname{IgG}_{2}$, and $\operatorname{IgM}$ was 9.7, 7.4, and $9.6 \%$, respectively.

Blood samples were collected from a jugular vein before first colostrum intake (d 1), $24 \mathrm{~h}$ after colostrum intake (d 2), before first MR intake (d 4), and subsequently on d $7,14,21,28,35,42,49,56,63$, 70 , and 77 in evacuated tubes (Vacuette; Greiner BioOne GmbH, Frickenhausen, Germany) by jugular vein puncture (Frieten et al., 2017). Blood samples were held on ice until centrifugation at $3,500 \times g$ for $10 \mathrm{~min}$ at room temperature. The plasma was pipetted into aliquots and stored at $-20^{\circ} \mathrm{C}$ until analysis. In tubes containing potassium oxalate $(2-4 \mathrm{mg} / \mathrm{mL})$ and sodium fluoride $(2-4 \mathrm{mg} / \mathrm{mL})$, plasma concentrations of total protein and albumin were analyzed. Tubes containing potassium-EDTA $(1.8 \mathrm{mg} / \mathrm{mL})$ were analyzed for plasma concentrations of fibrinogen, haptoglobin, serum amyloid A (SAA; d 1, 4, 7, 21, 35, 49, 63, and 77), and $\operatorname{IgG}_{1}, \operatorname{IgG}_{2}$, and $\operatorname{IgM}(\mathrm{d} 1,4,14,28,42,56$, and 77$)$. Total protein and albumin were analyzed spectrophotometrically (ABX Pentra 400, Horiba ABX, Montpellier, France) using the kits 553-412 (MTI-Diagnostics, Idstein, Germany) for total protein and A11A01664 (Horiba ABX) for albumin. The immunoglobulins were determined as described above for colostrum and as recently published (Gruse et al., 2016). The apparent efficiency of absorption (AEA) for $\operatorname{IgG}_{1}, \operatorname{IgG}_{2}$, IgM, and total $\mathrm{Ig}$ was calculated using the method from Quigley and Drewry (1998). For detection of SAA, a multispecies ELISA kit (no. TP-802, Tridelta Development, Maynooth, Ireland) was used. The detection limit of SAA was $9.4 \mathrm{mg} / \mathrm{L}$. The intra-assay coefficient of variation was $12.0 \%$. The haptoglobin concentration was analyzed using the guaiacol method developed by Jones and Mould (1984) with human haptoglobin Hp 2-2 (Sigma \#H9762) as a standard. The detection limit of haptoglobin was $0.02 \mathrm{~g} / \mathrm{L}$. Plasma fibrinogen was determined by rapid heat precipitation according to Millar et al. (1971).

Liver samples were collected on $\mathrm{d} 50 \pm 2$ and 80 \pm 2 (mean $\pm \mathrm{SD}$ ) from each calf by biopsy or after harvesting the calves (male calves at d 80 only; Frieten et al., 2017). Liver samples were flushed in ice-cold $0.9 \% \mathrm{NaCl}$ and frozen and pulverized in liquid nitrogen. The relative mRNA abundance of haptoglobin $(H P)$, fibrinogen $(F G A)$, and serum amyloid A2 (SAA2) genes was quantified as previously described (Saremi et al., 2012; Gruse et al., 2016). Primer sequences and PCR conditions for reference genes [low-density lipoprotein 10 (LRP10), emerin $(E M D)$, and RNA polymerase II (POLR2A)] and target genes of HP, FGA, and SAA2 were recently published (Saremi et al., 2012; Gruse et al., 2016; Schäff et al., 2016). The primer products were verified by sequencing with the BigDye Terminator v1.1 Cycle Sequencing kit and an ABI 3130 Genetic Analyzer (both from Thermo Fisher Scientific Inc., Waltham, MA). Real-time PCR was performed with the use of a LightCycler (F. Hoffman-La Roche AG, Basel, Switzerland); SYBR Green I (F. Hoffman-La Roche AG) was used as the fluorescent dye. Melting curve analysis and agarose gel electrophoresis were used to confirm the specificity of the PCR products. Quantification cycle values and amplification efficiencies obtained with the use of LinRegPCR version 2013.0 (Ruijter et al., 2013) were imported into qBASE+ version 2.6.1 (Biogazelle, Zwijnaarde, Belgium) for all subsequent calculations and quality controls (Schäff et al., 2016). The geometric mean of the reference gene abundances was applied for normalization. The data are presented as the ratio of the copy number of the respective gene of interest to the geometric mean of the reference gene abundance.

\section{Statistical Analysis}

All results were evaluated by SAS software, version 9.4 for Windows (SAS Institute Inc., Cary, NC). The behavior and body temperature, AEA, and blood plasma and liver tissue data were analyzed using the MIXED procedure of SAS with milk feeding intensity, butyrate supplementation, time, sex, and respective interactions as fixed effects in the ANOVA models. Repeated measures on every calf were observed using the REPEATED statement of the MIXED procedure and an unstructured type of block diagonal residual covariance matrix. Least squares means and their standard errors were computed for each fixed effect in the models, and all pair-wise differences of least squares means were tested with the Tukey-Kramer procedure. The SLICE statement of the MIXED procedure was used to conduct partitioned analyses of the least squares means for interactions. The concentrations of immunoglobulins in colostrum were analyzed by a general linear model (GLM) with treatment group as the main effect.

Health parameters as well as fecal score were evaluated by a logistic model using the GLIMMIX procedure 
of SAS (binomial distributed dependent variable, logistic link function) with milk feeding intensity, butyrate supplementation, sex, and season as fixed effects and their respective interactions. Repeated measures on the same calf were taken into account by the RESIDUAL option of the RANDOM STATEMENT of the GLIMMIX procedure using a compound symmetry type for the block diagonal residual covariance matrix. Effects and differences were defined as significant with $P$-values $<0.05$. Values are presented as least squares means \pm standard error if not declared otherwise.

\section{RESULTS}

\section{Performance, Behavior, and Health}

Feed intake and growth performance of these calves were recently published in a companion paper (Frieten et al., 2017) and are shown in Supplemental Table S2 (https://doi.org/10.3168/jds.2018-14542). In summary, milk, MR, and total nutrient intake were greater but concentrate intake was lower in Adl than in Res calves, resulting in a greater BW in Adl than in Res.

The number of rewarded visits (Figure 1A) at the automatic MR feeder differed with respect to the feeding regimen and butyrate treatment $(P<0.05)$, showing a greater number of rewarded visits in Adl than in Res $(P<0.05)$ in wk 5 and 10 and a greater number in $\mathrm{B}$ - than in $\mathrm{B}+(P<0.05)$ in wk 5 and 7 . Unrewarded visits (Figure 1B) at the automatic MR feeder were greater $(P<0.05)$ in Res than in Adl from wk 2 to 10 . The sucking rate (MR intake per min) increased $(P<0.01)$ from birth until the end of the trial in all groups (Figure 1C). The sucking rate was greater $(P$ $<0.05)$ in Res than in Adl from wk 2 to 5 and in wk 7 and 10 and was lower $(P<0.05)$ in $\mathrm{B}+$ than $\mathrm{B}-$ in wk 3 and 4 and from wk 6 to 11 . The sucking rate was highest $(P<0.05)$ in ResB - at wk 4 and 10. The MR intake per rewarded visit $(=$ meal size $)$ was greater $(P$ $<0.05)$ in Adl than in Res from wk 2 until wk 10 and was greater $(P<0.05)$ in $\mathrm{B}+$ than in $\mathrm{B}-$ in wk 2,3 , and 7 . The MR intake per rewarded visit decreased $(P$ $<0.05)$ after wk 9 of age in Adl calves because of linear MR reduction in these groups and was greater $(P<$ 0.05 ) in male than in female calves (mean MR intake per rewarded visit was $1.70 \pm 0.05$ and $1.56 \pm 0.05 \mathrm{~L} /$ visit for male and female calves, respectively, for wh 2 to 9 of age).

Vaccination did not negatively influence the health status of the calves, and season did not affect calves' health and incidence of disease. Rectal temperature (Table 1, Figure 2) increased $(P<0.01)$ after birth and peaked at $4 \mathrm{~d}$ of life in all groups and in Adl peaked again at $11 \mathrm{~d}$ of life. Mean body temperatures in wk 1 and 2 and on d 4, 9, 10, 11, 13, 14, and 19 were greater $(P<0.01)$ in Adl than in Res calves and were greater $(P<0.05)$ on $\mathrm{d} 18$ in $\mathrm{B}+$ than in $\mathrm{B}-$.

Fecal consistency (Table 1) showed significant differences with respect to feeding regimen and butyrate supplementation. In Adl, more calves $(P<0.05)$ exhibited smooth (score 3) and pasty (score 2 ) feces events and fewer $(P<0.05)$ well-formed (score 1$)$ events than in Res. The butyrate supplementation showed more $(P$ $<0.05)$ pasty (score 2$)$ events and fewer $(P<0.05)$ well-formed (score 1) feces events. The numbers of respiratory and naval diseases and veterinary treatments did not differ among groups (data not shown). Number of prophylactic and curative treatments (daily event) per calf was $9.7 \pm 0.9$ for calves born in autumn and winter and $9.2 \pm 1.3$ for calves born in spring and summer. Intestinal diseases of unknown origin appeared 8 times ( 3 calves in group ResB-, 2 calves in group ResB,+ 3 calves in group AdlB + , data not shown) during the entire trial period. No sex effect was detected on the health of calves.

\section{Immune Markers of Colostrum and Calves}

The concentrations of immunoglobulins in the first colostrum of calves' dams were similar among groups $\left(46.7 \pm 4.9 \mathrm{~g} / \mathrm{L}\right.$ for $\operatorname{IgG}_{1} ; 5.5 \pm 0.8 \mathrm{~g} / \mathrm{L}$ for $\operatorname{IgG}_{2} ; 9.6 \pm$ $1.1 \mathrm{~g} / \mathrm{L}$ for IgM). Intake of first colostrum was similar for all calves $(2.5 \pm 0.01 \mathrm{~L}$; Frieten et al., 2017). The AEA measurements were $29.7 \pm 2.5 \%$ for total immunoglobulins, $31.3 \pm 2.7 \%$ for $\operatorname{IgG}_{1}, 32.8 \pm 2.4 \%$ for $\mathrm{IgG}_{2}$, and $20.6 \pm 2.1 \%$ for IgM and were similar among groups.

Total protein concentration in blood plasma (Figure $3 \mathrm{~A})$ increased rapidly $(P<0.001)$ during the first 24 $\mathrm{h}$ of life in all groups and decreased thereafter $(P<$ $0.01)$ to a plateau of $52.9 \pm 0.9 \mathrm{~g} / \mathrm{L}$ in all calves. At the beginning of weaning, plasma total protein increased again until the end of the study in all groups. On $\mathrm{d} 21$ and 63 , the total protein concentration was greater $(P$ $<0.05)$ in Res than in Adl. Total protein was greater $(P<0.05)$ in female than in male calves (mean total protein concentration was $54.5 \pm 0.5$ and $53.3 \pm 0.5$ $\mathrm{g} / \mathrm{L}$ for female and male calves, respectively). Plasma $\mathrm{IgG}_{1}$ concentration (Figure 3B) was highest $(P<0.01)$ on d 4 , stayed near-constant after that at $7.4 \pm 0.5 \mathrm{~g} / \mathrm{L}$, and was greater $(P<0.05)$ in Res than in Adl on $\mathrm{d}$ 4 and 28. The plasma $\operatorname{IgG}_{2}$ concentration (Figure $3 \mathrm{C}$ ) increased $(P<0.01)$ up to d 4 , decreased $(P<0.01)$ to $\mathrm{d} 28$, and again increased $(P<0.01)$ until the end of the study. The $\operatorname{IgG}_{2}$ concentration was highest $(P$ $<0.05)$ in ResB+ on d 77. The concentration of IgM 
Table 1. Fecal consistency during the entire experimental period and rectal body temperature in the first 3 wk in calves fed milk and milk replacer (MR) either ad libitum or restrictively and MR supplemented with $0.24 \%$ butyrate (ResB+; AdlB+) or without (ResB-; AdlB-)

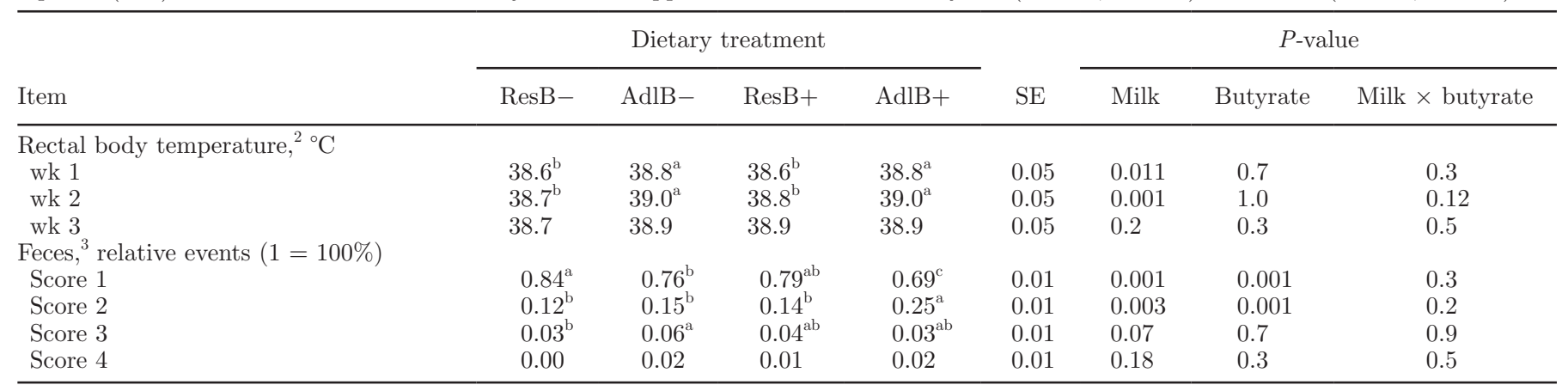

${ }^{\mathrm{a}-\mathrm{c}}$ Different letters within the same row indicate significant differences $(P<0.05)$.

${ }^{1}$ Values are LSM with SE.

${ }^{2}$ Rectal body temperature: data are presented as weekly means for the first 3 wk of life.

${ }^{3}$ Feces: score 1 = well formed; score 2 = pasty but formed; score $3=$ smooth, but persists on bedding; score $4=$ watery, runs through bedding.

A

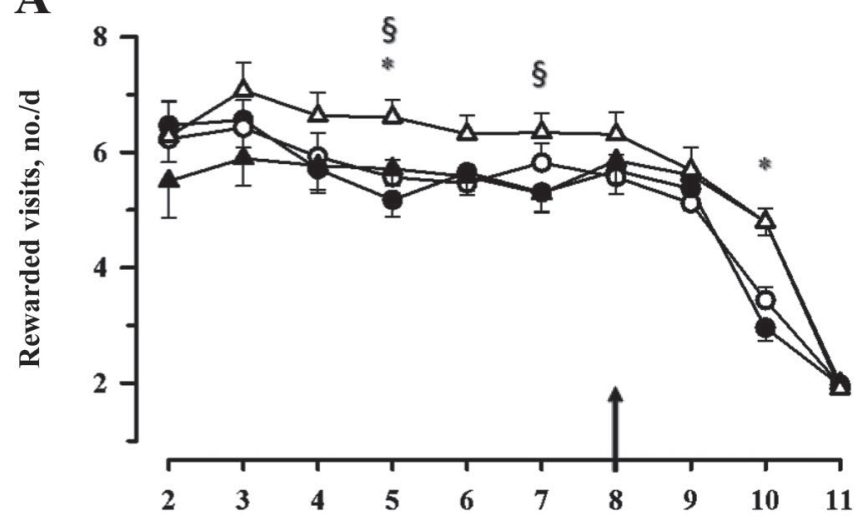

B

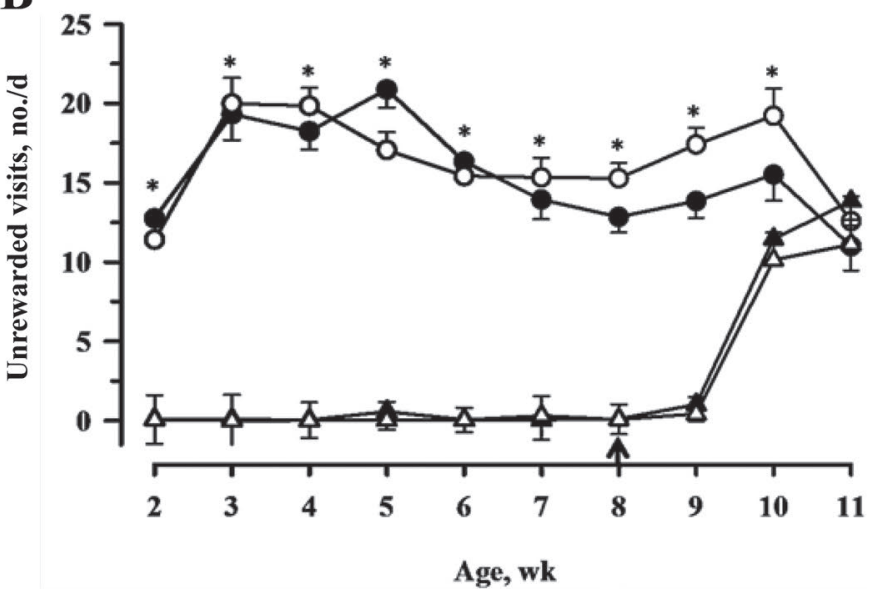

C

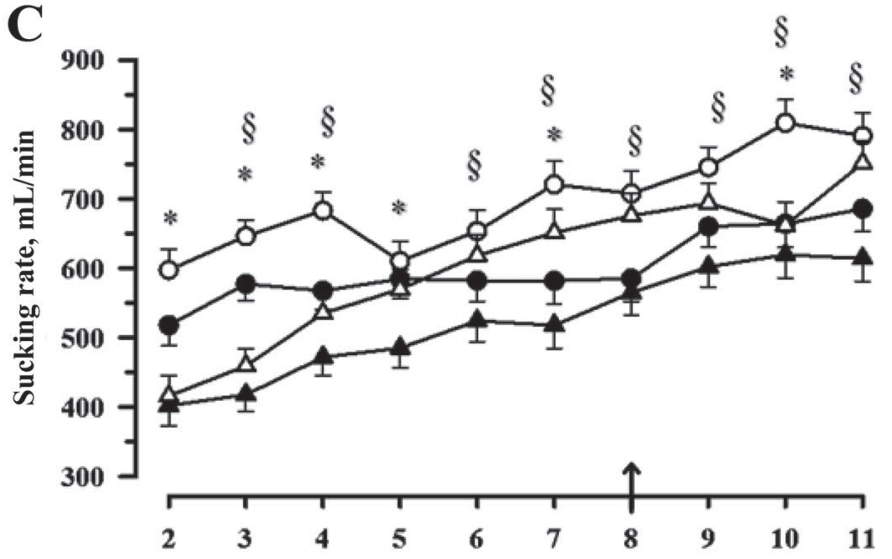

D

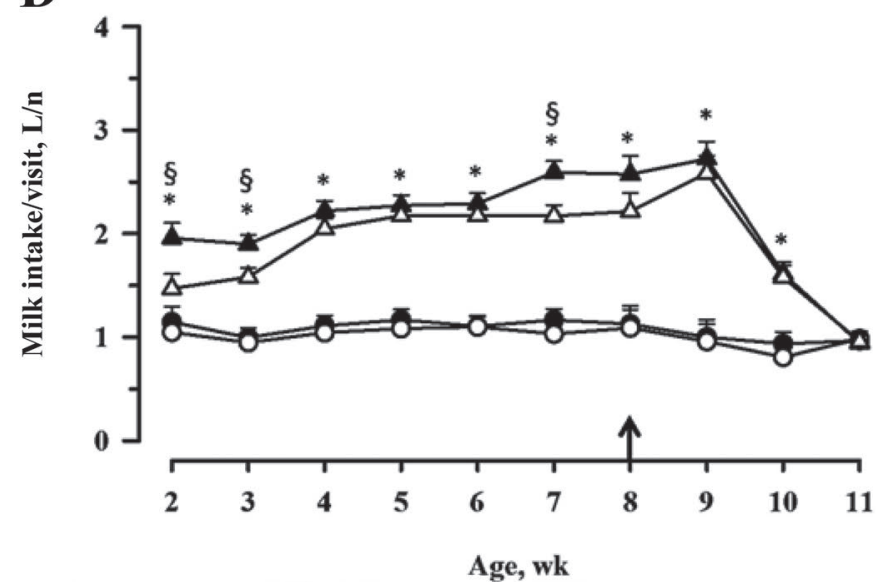

Figure 1. Sucking behavior. Rewarded visits (A), unrewarded visits (B), sucking rate (C), and milk intake per visit (D) at the automatic milk replacer (MR) feeder system in calves fed MR either ad libitum or restrictively and MR supplemented with $0.24 \%$ butyrate $(\boldsymbol{\Lambda}$ AdlB +; - ResB + ) or without ( $\Delta$ AdlB-; $\bigcirc$ ResB-). The MR intake was linearly reduced in wk 9 and 10 to $2 \mathrm{~L} / \mathrm{d}$ in wk 11 in all groups. The arrow marks the start of weaning. All data are presented as the LSM \pm SE. *Indicates the effect of feeding regimen $(P<0.05)$. $§$ Indicates the effect of butyrate supplementation $(P<0.05)$. 


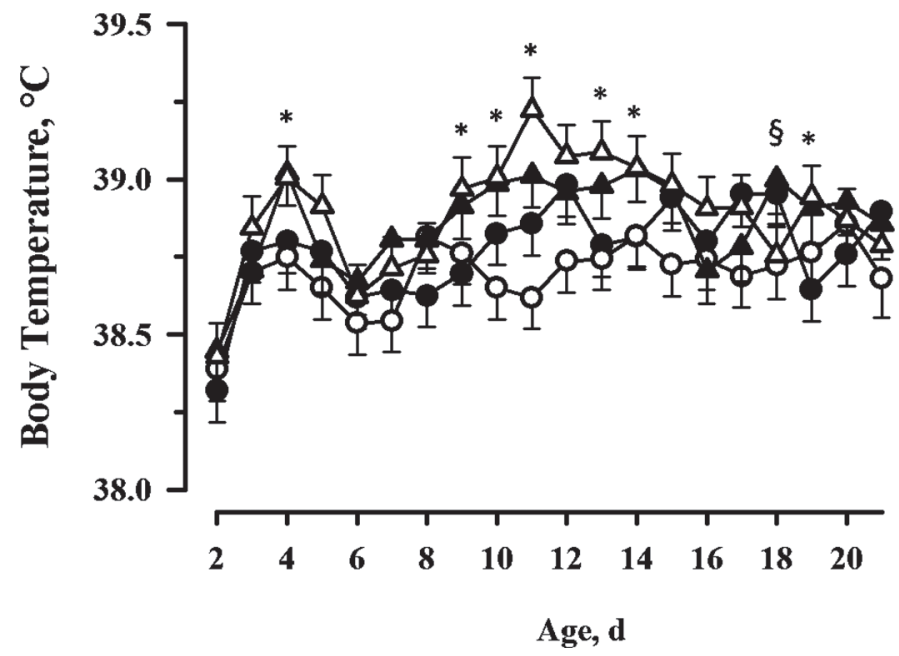

Figure 2. Daily rectal body temperature of calves fed milk replacer (MR) either ad libitum or restrictively and MR supplemented with $0.24 \%$ butyrate $(\Delta$ AdlB + ; $\bullet$ ResB + ) or without ( $\Delta$ AdlB-; O ResB-) for the first $3 \mathrm{wk}$ after birth. All data are presented as the $\mathrm{LSM} \pm \mathrm{SE}$. ${ }^{*}$ Significant differences between Adl and Res, $P<0.05$. $\S$ Significant differences between $\mathrm{B}+$ and $\mathrm{B}-, P<0.05$.

(Figure 3D) peaked $(P<0.01)$ in blood plasma at $\mathrm{d} 4$ and was greater $(P<0.05)$ in $\mathrm{B}+$ than in $\mathrm{B}-$ on $\mathrm{d} 1$, 4 , and 28 .

The plasma concentration of albumin (Figure 4A) first decreased $(P<0.01)$ until d 2 and then constantly increased $(P<0.01)$ up to the end of the trial in all groups. The plasma concentration of fibrinogen (Figure $4 \mathrm{~B})$ first increased $(P<0.01)$ up to $\mathrm{d} 4$ and then decreased $(P<0.01)$ until the start of weaning. At $\mathrm{d} 21$, 49 , and 63 , plasma fibrinogen was greater $(P<0.05)$ in Res than Adl. Fibrinogen in plasma was greater $(P$ $<0.05$ ) in female calves than in male calves (mean fibrinogen concentration was $4.01 \pm 0.1$ and $3.70 \pm$ $0.1 \mathrm{~g} / \mathrm{L}$ for female and male calves, respectively). The plasma concentration of SAA (Figure 4C) increased $(P$ $<0.01)$ to $\mathrm{d} 4$, then decreased $(P<0.01)$ until the end of the study, and tended to be greater $(P<0.1)$ in Adl than in Res on d 35 and 49. The plasma concentration of $\mathrm{Hp}$ was below the detection limit of $0.01 \mathrm{~g} / \mathrm{L}$ (data not shown), except for 2 female calves, which had high concentrations of $\mathrm{Hp}$, one on d $7(0.48 \mathrm{~g} / \mathrm{L})$ in ResB+ and the other on d $49(0.63 \mathrm{~g} / \mathrm{L})$ in AdlB + . For both events, inflammatory processes could be confirmed via the health protocol.

Hepatic gene expression of $F G A$ (Table 2) tended to increase $(P<0.1)$ from d 50 to 80 , and on $\mathrm{d} 80$ was greater $(P=0.05)$ in Adl than in Res. Gene expression of $S A A 2$ was greater $(P=0.05)$ on d 50 in Adl than in Res, and on d 80 was greater $(P<0.05)$ in ResB + than in ResB-. Gene expression of $H P$ did not differ with respect to time or treatment.

\section{DISCUSSION}

Ad libitum milk and MR feeding resulted in elevated milk intake and growth rate during the intensive milk feeding period and stimulated the systemic and hepatic IGF-I system, as recently published (Frieten et al., 2017, 2018). The greater MR intake in Adl calves during the ad libitum MR feeding period was particularly the consequence of greater meal sizes and was less a consequence of a greater number of rewarded visits per day in Adl than in Res calves. Ad libitum MR-fed calves on average drank 2.0 to $2.5 \mathrm{~L}$ per rewarded visit, whereas Res calves drank approximately half of that per rewarded visit. The meal size pattern measured herein fits previous studies (Senn et al., 2000; Hammon et al., 2002), but meal sizes up to $5.0 \mathrm{~L}$ per rewarded visit occurred in individual Adl calves. From our clinical investigations we concluded that this greater meal size did not lead to ruminal drinking, which supports previous investigations on meal size in calves (Appleby et al., 2001; Ellingsen et al., 2016). Therefore, a greater milk allowance does not necessarily result in a greater number of rewarded visits at the automatic MR feeder, as shown earlier (Hammon et al., 2002; Jensen and Holm, 2003). The meal size was slightly greater in male than in female calves, but the number of rewarded and unrewarded visits as well as the sucking rate were not affected by sex. In accordance with these findings, data on feed intake and growth performance were also influenced little by sex (Frieten et al., 2017).

Feeding restricted amounts of MR resulted in a much greater rate of unrewarded visits at the automatic MR feeder in Res than in Adl calves, which corresponds to previous findings (Hammon et al., 2002; Borderas et al., 2009; Korst et al., 2017). This great number of unrewarded visits was a classical sign of hunger in Res calves (Jensen and Holm, 2003; de Paula Vieira et al., 2008; de Passillé et al., 2011) and supports the concept that calves with restricted MR or milk intake do not cover the energy demands for maintenance and growth (Khan et al., 2011). As a consequence, the sucking rate at the automatic MR feeder, which corresponded to data from teat-fed calves (Appleby et al., 2001), was also greater in Res than in Adl. This finding probably indicated an elevated voracious appetite for MR consumption in Res calves because of hunger and restricted MR supply. Therefore, intensive feeding programs after birth that allow calves to drink milk or MR ad libitum increase animal welfare in calf rearing (von Keyserlingk et al., 2009).

Unrewarded visits increased in wk 10 during the weaning process in Adl calves but did not change in Res calves. Because concentrate intake was much lower in Adl than in Res in wk 10 (Frieten et al., 2017), Adl 
calves tried to cover their nutrient demands by MR intake, which was not possible anymore because the MR intake was reduced in Adl calves at that time. This finding indicates that the weaning process was too fast and too early for Adl, and Adl calves were not able to compensate for the reduced MR intake by adequate concentrate intake (Frieten et al., 2017). Therefore, the weaning protocol of the present study with a time frame of 2 wk could not avoid the temporary drop in nutrient intake and ADG in Adl calves (Frieten et al., 2017). Because intensive MR feeding programs require more attention to the weaning process (Steele et al., 2017), a protocol on MR reduction during weaning based on the increasing amount of solid feed intake or delayed weaning would be much more suitable (de Passillé and Rushen, 2012, 2016; Eckert et al., 2015).

The effects of the butyrate supplement on feeding behavior were most obvious in the sucking rate. The lower sucking rate in $\mathrm{B}+$ calves may arise from the taste of the MR with butyrate even though it was chemically bonded to calcium and sodium. However, MR intake was not affected by the butyrate supplement (Frieten et al., 2017), but slight effects on meal size and rewarded visits were observed in the present study, resulting in fewer rewarded visits but a greater meal size, especially in AdlB + calves. Although some small differences in feeding behavior were observed, the performance data were not significantly affected by butyrate supplementation (Frieten et al., 2017).

Intensive milk feeding and butyrate supplementation did not affect the health of the calves in the present study. In general, all calves were healthy, and clinical signs of diarrhea, pneumonia, or navel infection were rarely observed, supporting previous studies on intensive milk feeding in preweaning calves (Jasper and Weary, 2002; Maccari et al., 2015). In addition, no sea-
A

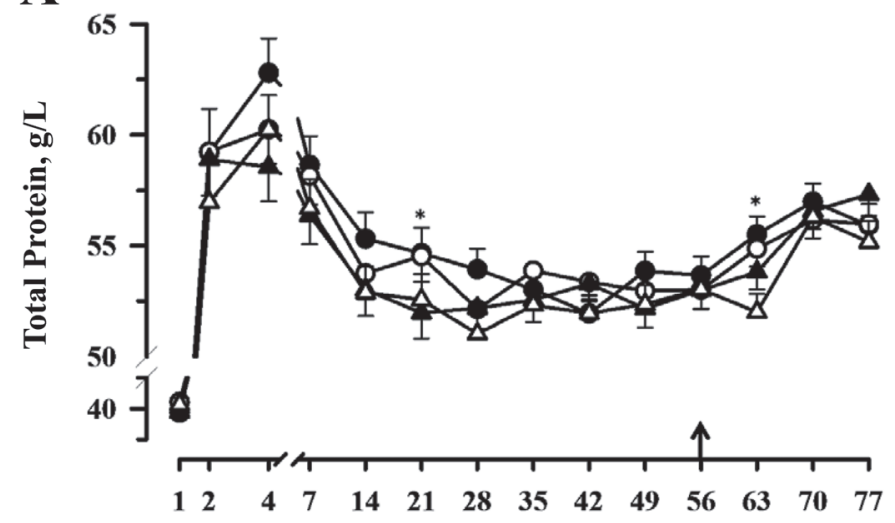

B

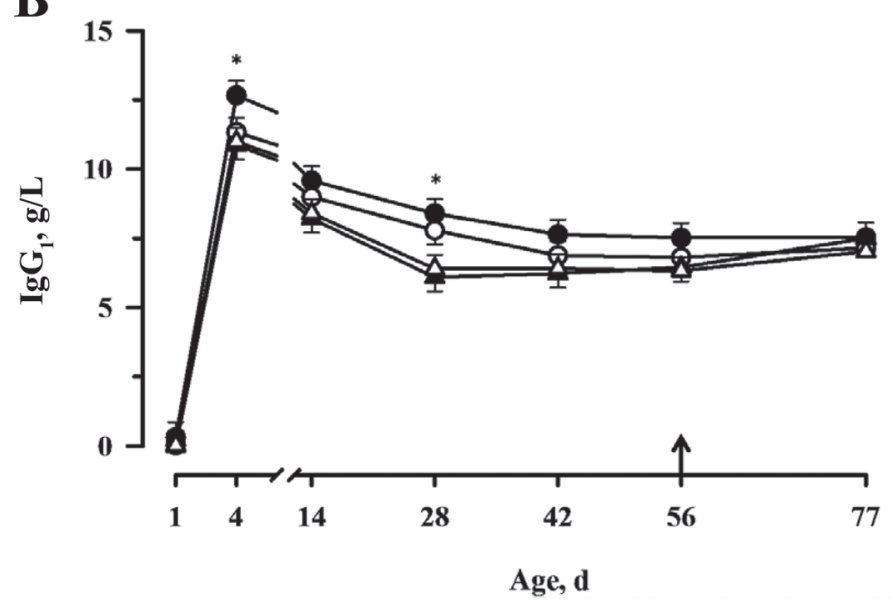

C

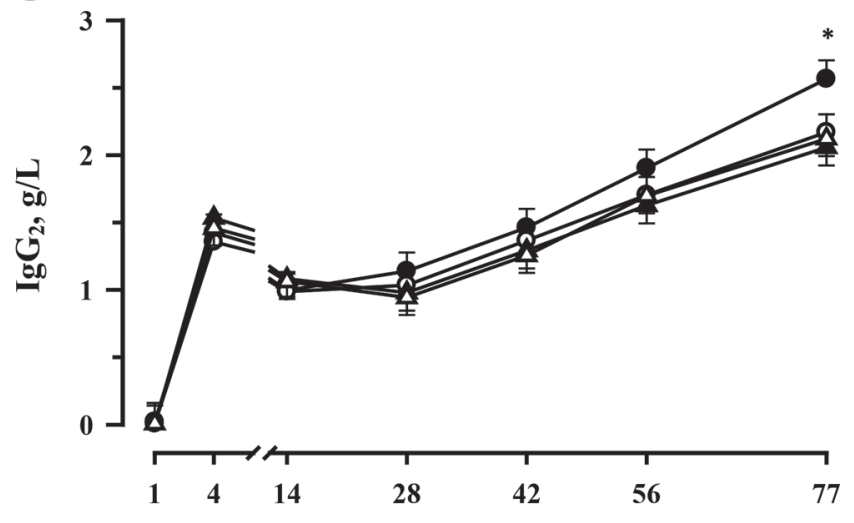

D

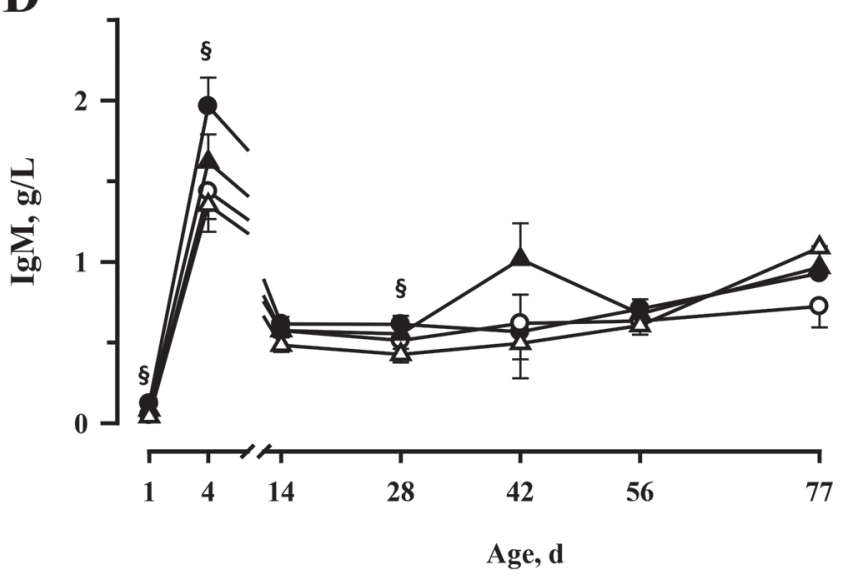

Figure 3. Total protein and immune status in blood plasma. Plasma concentrations of total protein $(A)$ and $\operatorname{IgG} G_{1}(B), \operatorname{IgG} 2(C)$, and $\operatorname{IgM}$ (D) in calves fed milk replacer (MR) either ad libitum or restrictively and MR supplemented with $0.24 \%$ butyrate $(\boldsymbol{\Lambda}$ AdlB+; $\bullet$ ResB+) or without ( $\Delta$ AdlB-; $\bigcirc$ ResB-). The MR intake was linearly reduced in wk 9 and 10 to $2 \mathrm{~L} / \mathrm{d}$ in wk 11 in all groups. The arrow marks the start of weaning. All data are presented as the LSM \pm SE. *Indicates the effect of feeding regimen $(P<0.05)$. $\S$ Indicates the effect of butyrate supplementation $(P<0.05)$. 

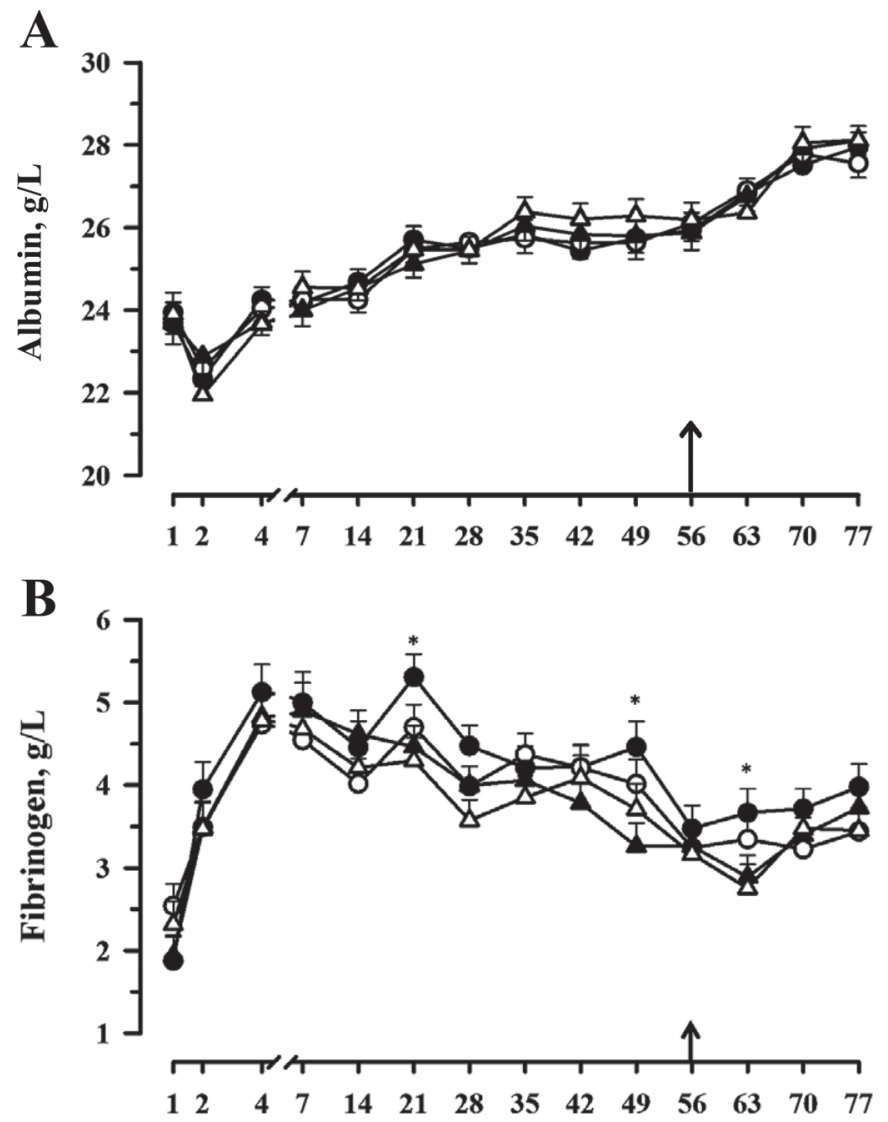

C

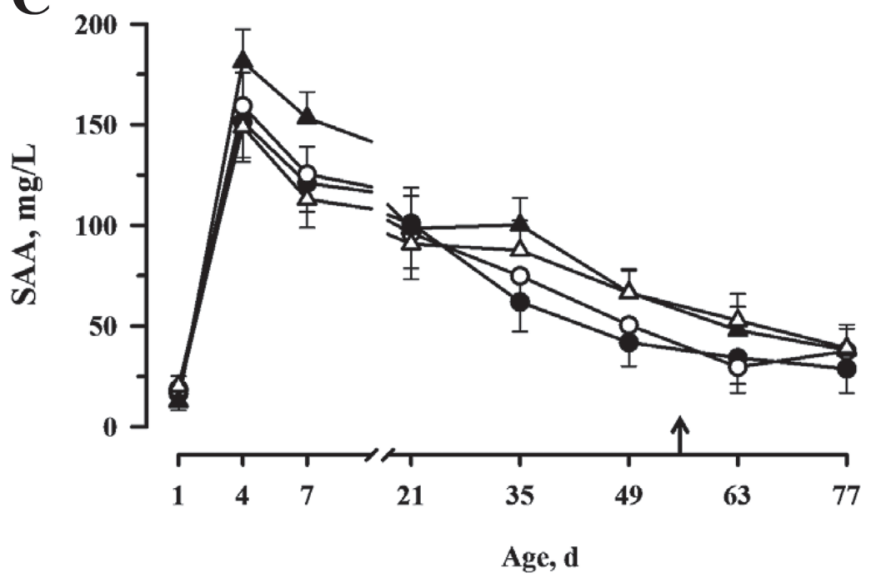

Age, d

Figure 4. Acute phase proteins in blood plasma. Plasma concentrations of albumin (A), fibrinogen (B), and serum amyloid A (SAA; C) in blood plasma in calves fed milk replacer (MR) either ad libitum or restrictively and MR supplemented with $0.24 \%$ butyrate ( $\mathbf{\Delta}$ AdlB+; ResB + ) or without ( $\Delta$ AdlB-; $\bigcirc$ ResB-) from wk 2 after birth until wk 9 . The MR intake was linearly reduced in wk 9 and 10 to $2 \mathrm{~L} / \mathrm{d}$ in wk 11 in all groups. The arrow marks the start of weaning. All data are presented as the LSM \pm SE. *Indicates the effect of feeding regimen $(P<0.05)$.

Table 2. Relative mRNA expression $\left(\log _{2}\right)$ of fibrinogen, haptoglobin, and serum amyloid A2 in liver samples from calves fed milk and milk replacer (MR) either ad libitum or restrictively and MR supplemented with $0.24 \%$ butyrate (ResB+; AdlB+) or without (ResB-; AdlB-)

\begin{tabular}{|c|c|c|c|c|c|c|c|c|c|}
\hline \multirow{3}{*}{$\begin{array}{l}\text { Relative mRNA } \\
\text { expression related } \\
\text { to reference genes }{ }^{1}\end{array}$} & \multirow{2}{*}{\multicolumn{4}{|c|}{ Dietary treatment }} & \multirow[b]{3}{*}{$\mathrm{SE}$} & \multicolumn{4}{|c|}{ Fixed effect, $P$-value ${ }^{2}$} \\
\hline & & & & & & \multirow{2}{*}{$\begin{array}{c}\text { Milk } \\
\begin{array}{c}\text { Milk } \times \\
\text { time }\end{array}\end{array}$} & \multirow{2}{*}{$\begin{array}{c}\text { Butyrate } \\
\text { Milk } \times \\
\text { butyrate }\end{array}$} & \multirow{2}{*}{$\frac{\text { Time }}{\begin{array}{c}\text { Butyrate } \\
\text { time }\end{array}}$} & \multirow[b]{2}{*}{ Sex } \\
\hline & ResB- & AdlB-- & ResB+ & AdlB + & & & & & \\
\hline \multicolumn{10}{|l|}{$F G A$} \\
\hline d 50 & 84.3 & 89.7 & 92.0 & 90.5 & 10.9 & 0.07 & 0.35 & 0.09 & 0.13 \\
\hline d 50 & 85.3 & 269.2 & 317.3 & 290.8 & 110.1 & 0.29 & 0.8 & 1.0 & \multirow[t]{2}{*}{0.3} \\
\hline d 80 & 168.6 & 552.7 & 204.8 & 245.7 & 183.9 & 0.7 & 0.2 & 0.2 & \\
\hline \multicolumn{10}{|l|}{$S A A 2$} \\
\hline d 50 & 4.79 & 7.74 & 6.29 & 8.01 & 1.15 & 0.4 & 0.07 & 0.3 & \multirow[t]{2}{*}{0.12} \\
\hline d 80 & $4.65^{\mathrm{b}}$ & $5.63^{\mathrm{ab}}$ & $8.23^{\mathrm{a}}$ & $5.73^{\mathrm{ab}}$ & 0.83 & 0.02 & 0.2 & 0.4 & \\
\hline
\end{tabular}

${ }_{\mathrm{a}, \mathrm{b}}$ Different letters within the same row indicate significant differences $(P<0.05)$.

${ }^{1} F G A=$ fibrinogen; $H P=$ haptoglobin; $S A A 2=$ serum amyloid A2. Values are presented as LSM with SE.

${ }^{2}$ Fixed effects are presented in 2 rows: The first row indicates $P$-value for milk (ad libitum versus restrictive), butyrate supplementation, time, and sex; the second row indicates $P$-values for interactions. 
sonal effects on calf health, as recently discussed (Khan et al., 2011), could be found, which was also noticed by Maccari et al. (2015). The slightly looser feces in Adl than in Res calves was probably the consequence of the greater milk intake in Adl calves, but calves did not suffer from clinical diarrhea. A greater rate of loose feces after intensive MR feeding without clinical diarrhea was recently reported (Liang et al., 2016; Jorgensen et al., 2017; Todd et al., 2017). The high level of milk feeding does not imply the occurrence of diarrhea in preweaning calves (Khan et al., 2011; Jorgensen et al., 2017). Butyrate supplementation reduced fecal consistency, but previous studies indicated no effect of butyrate supplementation on the fecal scores of preweaning calves (Guilloteau et al., 2010; Górka et al., 2011), and the greater rate of loose feces in butyrate-supplemented calves was not of clinical relevance. In addition, butyrate has anti-secretory effects in the intestine and, therefore, should normally increase fecal consistency (Canani et al., 2011). The greater rectal body temperature in Adl than in Res calves during the first and second weeks of age was probably a consequence of a greater metabolic rate in Adl calves, indicated by the greater growth rate and the stimulation of the IGF-I system in Adl calves (Schäff et al., 2016; Frieten et al., 2017, 2018).

The effects of ad libitum milk feeding and butyrate treatment on the establishment of passive immunity were rare. The plasma concentrations of total protein and immunoglobulins indicated a sufficient supply of immunoglobulins because the plasma concentrations were beyond the critical level for the failure of passive immunoglobulin transfer (Weaver et al., 2000; Godden, 2008; Furman-Fratczak et al., 2011). The well-established passive immunity in all groups resulted from comparable high immunoglobulin concentrations in the colostrum milkings of individual cows and the same immunoglobulin absorption efficiency rates among all groups. Immunoglobulin concentrations in colostrum and AEA correspond to known values from the literature (Quigley and Drewry, 1998; Weaver et al., 2000; Godden, 2008). The adequate passive immunity in all calves might be an additional reason for the low incidence of disease in the present study. Minor differences with slightly lower plasma concentrations of total protein and $\operatorname{IgG}_{1}, \operatorname{IgG}_{2}$, and IgM in Adl calves were probably due to greater dilution effects because of increased liquid intake in Adl calves and were also observed in a previous study with ad libitum MR feeding (Schäff et al., 2016). The elevated plasma concentrations of IgM in $\mathrm{B}+$ calves on $\mathrm{d} 1$ and 4 were not obvious because feeding of butyrate started after blood sampling on d 4 of age and there were no differences among treatments with respect to colostral IgM. The greater IgM plasma concentration in $\mathrm{B}+$ calves at $\mathrm{d} 28$ was in contrast to a previous study, where a negative effect of isobutyrate on IgM plasma concentration was reported (Baumwart et al., 1977).

Contrary to findings from Schäff et al. (2016), plasma albumin concentration was similar in all groups during the entire trial period, without any dilution effect by liquid feed intake. Albumin is a negative acute phase protein with decreasing levels during the inflammatory response (Tothova et al., 2014), whereas fibrinogen, SAA, and haptoglobin are used as indicators of inflammatory and traumatic disease and are markers of infection in cattle (Jawor et al., 2008; Eckersall and Bell, 2010; Tothova et al., 2014). Plasma fibrinogen increased in all calves during the first week of life, afterward decreased with age, but showed partially greater fibrinogen concentration in Res than in Adl calves, which supports previous findings (Schäff et al., 2016). Interestingly, the opposite was true for hepatic abundance of $F G A$ mRNA, which tended to increase with age and was greater in Adl than in Res calves at the end of the study. Plasma SAA concentration also increased after birth and decreased from d 4 on, a time pattern that was previously published (Orro et al., 2008). Plasma SAA tended to be minimally greater in Adl than in Res calves, consistent with a greater hepatic mRNA abundance on d 50 in Adl than in Res. However, the slightly elevated SAA status may not point to an enhanced inflammatory status in Adl because plasma haptoglobin showed almost no response, and hepatic gene expression of haptoglobin did not differ among groups. Plasma haptoglobin was also not affected by intensive milk feeding in previous calf studies (Obeidat et al., 2013; Schäff et al., 2016). Haptoglobin is often below the detection limit in healthy calves (Furman-Fratczak et al., 2011), and its sensitivity when used alone as a diagnostic test for individual calves is low (Murray et al., 2014). Instead, an enhanced inflammatory response is indicated by a distinct increase in positive acute phase proteins (Ganheim et al., 2007; Hajimohammadi et al., 2013; Tothova et al., 2014), which was not observed in the present study. These results fit the low incidence of disease in the present study. Evidence for enhanced stress during weaning indicated by an increase in acute phase proteins (Kim et al., 2011) could also not be found in the present study. Furthermore, our data indicated no signs of physical stress during the experimental period in any of the groups (Alsemgeest et al., 1995). The immediate increase in plasma fibrinogen and SAA in calves during the first days of life may point to the absorption of these proteins from colostrum because both proteins are present in colostrum (Hernandez-Castellano et al., 2014; Tothova et al., 2015), but at least for SAA, absorption from colostrum does obviously not occur (Orro 
et al., 2008). To clarify this issue, further studies are needed.

\section{CONCLUSIONS}

Ad libitum MR feeding for 8 wk affected feeding behavior by reducing the evidence of hunger, and therefore improved animal welfare, but the weaning process was too fast to avoid a temporary reduction in nutrient intake in Adl calves. To use the benefits of the ad libitum MR feeding strategy, it is necessary to implement advanced weaning management to stimulate solid feed intake earlier or perform a delayed weaning strategy. As most of the calves showed few to no health problems, no further improvement of the health or the immune status was observed either by ad libitum milk feeding or by butyrate supplementation. Most likely, health was more affected by first colostrum intake and immunoglobulin level in calves, which did not differ among groups. Butyrate supplementation did not stimulate postnatal growth performance but showed some divergent effects on feeding behavior that should be investigated in more detail in further studies.

\section{ACKNOWLEDGMENTS}

We gratefully thank the colleagues of the Educational and Research Centre for Animal Husbandry, Hofgut Neumuehle, and the Animal Nutrition team and students at the University of Applied Sciences Bingen for realizing the project. The authors are grateful to C. Reiko [Leibniz Institute for Farm Animal Biology (FBN), Dummerstorf, Germany] for excellent laboratory work. The work was supported by Wrocław Centre of Biotechnology, Programme Leading National Research Centre (KNOW), Wroclaw, Poland, for the years $2014-2018$.

\section{REFERENCES}

Alsemgeest, S. P., I. E. Lambooy, H. K. Wierenga, S. J. Dieleman, B. Meerkerk, A. M. van Ederen, and T. A. Niewold. 1995. Influence of physical stress on the plasma concentration of serum amyloid-A (SAA) and haptoglobin (Hp) in calves. Vet. Q. 17:9-12.

Appleby, M. C., D. M. Weary, and B. Chua. 2001. Performance and feeding behaviour of calves on ad libitum milk from artificial teats. Appl. Anim. Behav. Sci. 74:191-201. https://doi.org/10.1016/ S0168-1591(01)00171-X.

Ballou, M. A. 2012. Immune responses of Holstein and Jersey calves during the preweaning and immediate postweaned periods when fed varying planes of milk replacer. J. Dairy Sci. 95:7319-7330.

Ballou, M. A., D. L. Hanson, C. J. Cobb, B. S. Obeidat, M. D. Sellers, A. R. Pepper-Yowell, J. A. Carroll, T. J. Earleywine, and S. D. Lawhon. 2015. Plane of nutrition influences the performance, innate leukocyte responses, and resistance to an oral Salmonella enterica serotype Typhimurium challenge in Jersey calves. J. Dairy Sci. 98:1972-1982. https://doi.org/10.3168/jds.2014-8783.
Baumwart, A. L., L. J. Bush, M. Mungle, and L. D. Corley. 1977. Effect of potassium isobutyrate on absorption of immunoglobulins from colostrum by calves. J. Dairy Sci. 60:759-762.

Borderas, T. F., A. M. de Passillé, and J. Rushen. 2009. Feeding behavior of calves fed small or large amounts of milk. J. Dairy Sci. 92:2843-2852. https://doi.org/10.3168/jds.2008-1886.

Canani, R. B., M. D. Costanzo, L. Leone, M. Pedata, R. Meli, and A. Calignano. 2011. Potential beneficial effects of butyrate in intestinal and extraintestinal diseases. World J. Gastroenterol. 17:15191528. https://doi.org/10.3748/wjg.v17.i12.1519.

Clark, R. 1997. The somatogenic hormones and insulin-like growth factor-1: Stimulators of lymphopoiesis and immune function. Endocr. Rev. 18:157-179. https://doi.org/10.1210/edrv.18.2.0296.

de Passillé, A. M., T. F. Borderas, and J. Rushen. 2011. Weaning age of calves fed a high milk allowance by automated feeders: Effects on feed, water, and energy intake, behavioral signs of hunger, and weight gains. J. Dairy Sci. 94:1401-1408. https://doi.org/10.3168/ jds.2010-3441.

de Passillé, A. M., M. Rabeyrin, and J. Rushen. 2016. Associations between milk intake and activity in the first days of a calf's life and later growth and health. Appl. Anim. Behav. Sci. 175:2-7. https:// doi.org/10.1016/j.applanim.2014.10.002.

de Passillé, A. M., and J. Rushen. 2012. Adjusting the weaning age of calves fed by automated feeders according to individual intakes of solid feed. J. Dairy Sci. 95:5292-5298. https://doi.org/10.3168/ jds.2012-5521.

de Passillé, A. M., and J. Rushen. 2016. Using automated feeders to wean calves fed large amounts of milk according to their ability to eat solid feed. J. Dairy Sci. 99:3578-3583. https://doi.org/10 $.3168 /$ jds.2015-10259.

de Paula Vieira, A., V. Guesdon, A. M. de Passillé, M. A. G. von Keyserlingk, and D. M. Weary. 2008. Behavioural indicators of hunger in dairy calves. Appl. Anim. Behav. Sci. 109:180-189.

Eckersall, P. D., and R. Bell. 2010. Acute phase proteins: Biomarkers of infection and inflammation in veterinary medicine. Vet. J 185:23-27.

Eckert, E., H. E. Brown, K. E. Leslie, T. J. DeVries, and M. A. Steele. 2015. Weaning age affects growth, feed intake, gastrointestinal development, and behavior in Holstein calves fed an elevated plane of nutrition during the preweaning stage. J. Dairy Sci. 98:6315-6326. https://doi.org/10.3168/jds.2014-9062.

Egli, C. P., and J. W. Blum. 1998. Clinical, haematological, metabolic and endocrine traits during the first three months of life of suckling Simmentaler calves held in a cow-calf operation. Zentralbl. Veterinarmed. A 45:99-118.

Ellingsen, K., C. M. Mejdell, N. Ottesen, S. Larsen, and A. M. Grondahl. 2016. The effect of large milk meals on digestive physiology and behavior in dairy calves. Physiol. Behav. 154:169-174.

FAWC. 2015. Opinion on the welfare implications of nutritional management strategies for artificially-reared calves from birth to weaning. Farm Animal Welfare Committee, University of Bristol, Bristol, UK.

Frieten, D., C. Gerbert, C. Koch, G. Dusel, K. Eder, A. Hoeflich, B. Mielenz, and H. M. Hammon. 2018. Influence of ad libitum milk replacer feeding and butyrate supplementation on the systemic and hepatic insulin-like growth factor I and its binding proteins in Holstein calves. J. Dairy Sci. 101:1661-1672. https://doi.org/10 $.3168 /$ jds.2017-13603.

Frieten, D., C. Gerbert, C. Koch, G. Dusel, K. Eder, E. Kanitz, J. M. Weitzel, and H. M. Hammon. 2017. Ad libitum milk replacer feeding, but not butyrate supplementation, affects growth performance as well as metabolic and endocrine traits in Holstein calves. J. Dairy Sci. 100:6648-6661. https://doi.org/10.3168/jds.2017-12722.

Furman-Fratczak, K., A. Rzasa, and T. Stefaniak. 2011. The influence of colostral immunoglobulin concentration in heifer calves' serum on their health and growth. J. Dairy Sci. 94:5536-5543. https:// doi.org/10.3168/jds.2010-3253.

Ganheim, C., S. Alenius, and W. K. Persson. 2007. Acute phase proteins as indicators of calf herd health. Vet. J. 173:645-651.

Godden, S. 2008. Colostrum management for dairy calves. Vet. Clin. North Am. Food Anim. Pract. 24:19-39. 
Górka, P., Z. M. Kowalski, P. Pietrzak, A. Kotunia, W. Jagusiak, J. J. Holst, R. Guilloteau, and R. Zabielski. 2011. Effect of method of delivery of sodium butyrate on rumen development in newborn calves. J. Dairy Sci. 94:5578-5588. https://doi.org/10.3168/jds 2011-4166

Gruse, J., E. Kanitz, J. M. Weitzel, A. Tuchscherer, T. Stefaniak, P. Jawor, W. Siegfried, and H. M. Hammon. 2016. Quercentin feeding in newborn dairy calves cannot compensate colostrum deprivation: Study on metabolic, antioxidative and inflammatory traits. PLoS One 11:e0146932. https://doi.org/10.1371/journal.pone.0146932.

Guilloteau, P., L. Martin, V. Eeckhaut, R. Ducatelle, R. Zabielski, and F. Van Immerseel. 2010. From the gut to the peripheral tissues: The multiple effects of butyrate. Nutr. Res. Rev. 23:366-384.

Hajimohammadi, A., S. Nazifi, M. Ansari-Lari, M. Khoshmanzar, and S. Bigdeli. 2013. Identifying relationships among acute phase proteins (haptoglobin, serum amyloid A, fibrinogen, ceruloplasmin) and clinical findings in dairy calf diarrhea. Comp. Clin. Pathol. $22: 227-232$.

Hammon, H. M., D. Frieten, C. Gerbert, C. Koch, G. Dusel, R. Weikard, and C. Kühn. 2018. Different milk diets have substantial effects on the jejunal mucosal immune system of pre-weaning calves, as demonstrated by whole transcriptome sequencing. Sci. Rep. 8:1693. https://doi.org/10.1038/s41598-018-19954-2.

Hammon, H. M., G. Schiessler, A. Nussbaum, and J. W. Blum. 2002. Feed intake patterns, growth performance, and metabolic and endocrine traits in calves fed unlimited amounts of colostrum and milk by automate, starting in the neonatal period. J. Dairy Sci. 85:3352-3362.

Hernandez-Castellano, L. E., A. M. Almeida, N. Castro, and A. Argueello. 2014. The colostrum proteome, ruminant nutrition and immunity: A review. Curr. Protein Pept. Sci. 15:64-74.

Hill, T. M., J. D. Quigley, H. G. Bateman, F. X. Suarez-Mena, T. S. Dennis, and R. L. Schlotterbeck. 2016. Effect of milk replacer program on calf performance and digestion of nutrients in dairy calves to 4 months of age. J. Dairy Sci. 99:8103-8110. https://doi .org/10.3168/jds.2016-11239.

Hulbert, L. E., and S. J. Moisa. 2016. Stress, immunity, and the management of calves. J. Dairy Sci. 99:3199-3216. https://doi.org/10 $.3168 /$ jds.2015-10198.

Jasper, J., and D. M. Weary. 2002. Effects of ad libitum milk intake on dairy calves. J. Dairy Sci. 85:3054-3058. https://doi.org/10.3168/ jds.S0022-0302(02)74391-9.

Jawor, P., S. Steiner, T. Stefaniak, W. Baumgartner, and A. Rzasa. 2008. Determination of selected acute phase proteins during the treatment of limb diseases in dairy cows. Vet. Med. (Praha) 53:173-183.

Jensen, M. B., and L. Holm. 2003. The effect of milk flow rate and milk allowance on feeding related behaviour in dairy calves fed by computer controlled milk feeders. Appl. Anim. Behav. Sci. 82:87-100.

Jiang, Y., W. Zhang, F. Gao, and G. Zhou. 2015. Effect of sodium butyrate on intestinal inflammatory response to lipopolysaccharide in broiler chickens. Can. J. Anim. Sci. 95:389-395.

Jones, G. E., and D. L. Mould. 1984. Adaptation of the guaiacol (peroxidase) test for haptoglobins to a microtitration plate system. Res. Vet. Sci. 37:87-92.

Jorgensen, M. W., A. Adams-Progar, A. M. de Passille, J. Rushen, S. M. Godden, and H. Chester-Jones. 2017. Factors associated with dairy calf health in automated feeding systems in the Upper Midwest United States. J. Dairy Sci. 100:5675-5686. https://doi.org/ 10.3168/jds.2016-12501.

Khan, M. A., A. Bach, D. M. Weary, and M. A. G. von Keyserlingk. 2016. Invited review: Transitioning from milk to solid feed in dairy heifers. J. Dairy Sci. 99:885-902. https://doi.org/10.3168/jds.2015 $-9975$.

Khan, M. A., D. M. Weary, and M. A. von Keyserlingk. 2011. Invited review: Effects of milk ration on solid feed intake, weaning, and performance in dairy heifers. J. Dairy Sci. 94:1071-1081.

Kim, M. H., J. Y. Yang, S. D. Upadhaya, H. J. Lee, C. H. Yun, and J. K. Ha. 2011. The stress of weaning influences serum levels of acute-phase proteins, iron-binding proteins, inflammatory cyto- kines, cortisol, and leukocyte subsets in Holstein calves. J. Vet. Sci. 12:151-157. https://doi.org/10.4142/jvs.2011.12.2.151.

Korst, M., C. Koch, J. Kesser, U. Müller, F.-J. Romberg, J. Rehage, K. Eder, and H. Sauerwein. 2017. Different milk feeding intensities during the first 4 weeks of rearing in dairy calves: Part 1: Effects on performance and production from birth over the first lactation. J. Dairy Sci. 100:3096-3108. https://doi.org/10.3168/ jds.2016-11594.

Liang, Y., J. A. Carroll, and M. A. Ballou. 2016. The digestive system of 1-week-old Jersey calves is well suited to digest, absorb, and incorporate protein and energy into tissue growth even when calves are fed a high plane of milk replacer. J. Dairy Sci. 99:1929-1937. https://doi.org/10.3168/jds.2015-9895.

Maccari, P., S. Wiedemannn, H.-P. Kunz, M. Piechotta, P. Sanftleben, and M. Kaske. 2015. Effects of two different rearing protocols for Holstein bull calves in the first 3 weeks of life on health status, metabolism and subsequent performance. J. Anim. Physiol. Anim. Nutr. (Berl.) 99:737-746. https://doi.org/10.1111/jpn.12241.

Mahmoud, M. E., F. A. Mahmoud, and A. E. Ahmed. 2016. Impacts of self- and cross-sucking on cattle health and performance. Vet. World 9:922-928.

Mee, J. F. 2013. Why do so many calves die on modern dairy farms and what can we do about calf welfare in the future? Animals (Basel) 3:1036-1057.

Millar, H., J. Simpson, and A. Stalker. 1971. An evaluation of the heat precipitation method for plasma fibrinogen estimation. J. Clin. Pathol. 24:827-830.

Miller-Cushon, E. K., and T. J. DeVries. 2015. Invited review: Development and expression of dairy calf feeding behavior. Can. J. Anim. Sci. 95:341-350.

Murray, C. F., M. C. Windeyer, T. F. Duffield, D. B. Haley, D. L. Pearl, K. M. Waalderbos, and K. E. Leslie. 2014. Associations of serum haptoglobin in newborn dairy calves with health, growth, and mortality up to 4 months of age. J. Dairy Sci. 97:7844-7855. https://doi.org/10.3168/jds.2014-8465.

Obeidat, B. S., C. J. Cobb, M. D. Sellers, A. R. Pepper-Yowell, T. J. Earleywine, and M. A. Ballou. 2013. Plane of nutrition during the preweaning period but not the grower phase influences the neutrophil activity of Holstein calves. J. Dairy Sci. 96:7155-7166. https://doi.org/10.3168/jds.2013-6699.

Ollivett, T. L., D. V. Nydam, T. C. Linden, D. D. Bowman, and M. E. Van Amburgh. 2012. Effect of nutritional plane on health and performance in dairy calves after experimental infection with Cryptosporidium parvum. J. Am. Vet. Med. Assoc. 241:1514-1520. 10.2460/javma.241.11.1514.

Orro, T., S. Jacobsen, J. P. Lepage, T. Niewold, S. Alasuutari, and T. Soveri. 2008. Temporal changes in serum concentrations of acute phase proteins in newborn dairy calves. Vet. J. 176:182-187.

Quigley, J. D., and J. J. Drewry. 1998. Nutrient and immunity transfer from cow to calf pre- and postcalving. J. Dairy Sci. 81:2779-2790.

Quigley, J. D., T. M. Hill, L. L. Deikun, and R. L. Schlotterbeck. 2017. Effects of amount of colostrum replacer, amount of milk replacer, and housing cleanliness on health, growth, and intake of Holstein calves to 8 weeks of age. J. Dairy Sci. 100:9177-9185. https://doi .org/10.3168/jds.2017-12784.

Quigley, J. D., T. A. Wolfe, and T. H. Elsasser. 2006. Effects of additional milk replacer feeding on calf health, growth, and selected blood metabolites in calves. J. Dairy Sci. 89:207-216.

Ruijter, J. M., M. W. Pfaffl, S. Zhao, A. N. Spiess, G. Boggy, J. Blom, R. G. Rutledge, D. Sisti, A. Lievens, K. De Preter, S. Derveaux, J. Hellemans, and J. Vandesompele. 2013. Evaluation of qPCR curve analysis methods for reliable biomarker discovery: Bias, resolution, precision, and implications. Methods 59:32-46. https://doi.org/10 .1016/j.ymeth.2012.08.011.

Saremi, B., H. Sauerwein, S. Dänicke, and M. Mielenz. 2012. Technical note: Identification of reference genes for gene expression studies in different bovine tissues focusing on different fat depots. J. Dairy Sci. 95:3131-3138. https://doi.org/10.3168/jds.2011-4803.

Schäff, C. T., J. Gruse, J. Maciej, M. Mielenz, E. Wirthgen, A. Hoeflich, M. Schmicke, R. Pfuhl, P. Jawor, T. Stefaniak, and H. 
M. Hammon. 2016. Effects of feeding milk replacer ad libitum or in restricted amounts for the first five weeks of life on the growth, metabolic adaptation, and immune status of newborn calves. PLoS One 11:e0168974.

Schiessler, G., A. Nussbaum, H. M. Hammon, and J. W. Blum. 2002. Calves sucking, colostrum and milk from their dams or from an automatic feeding station starting in the neonatal period: Metabolic and endocrine traits and growth performance. Anim. Sci. 74:431-444. https://doi.org/10.1017/S1357729800052589.

School of Veterinary Medicine. 2017. University of Wisconsin-Madison, Calf health scoring chart, Accessed Jan. 20, 2012. https:// www.vetmed.wisc.edu/dms/fapm/fapmtools/8calf/calf_health _scoring_chart.pdf.

Senn, M., S. Gross-Lüem, H. Leuenberger, and W. Langhans. 2000 Meal patterns and meal-induced metabolic changes in calves fed milk ad lib. Physiol. Behav. 70:189-195.

Steele, M. A., J. H. Doelman, L. N. Leal, F. Soberon, M. Carson, and J. A. Metcalf. 2017. Abrupt weaning reduces postweaning growth and is associated with alterations in gastrointestinal markers of development in dairy calves fed an elevated plane of nutrition dur- ing the preweaning period. J. Dairy Sci. 100:5390-5399. https:// doi.org/10.3168/jds.2016-12310.

Todd, C. G., K. E. Leslie, S. T. Millman, V. Bielmann, N. G. Anderson, J. M. Sargeant, and T. J. DeVries. 2017. Clinical trial on the effects of a free-access acidified milk replacer feeding program on the health and growth of dairy replacement heifers and veal calves. J. Dairy Sci. 100:713-725. https://doi.org/10.3168/jds.2016-11401.

Tothova, C., O. Nagy, and G. Kovac. 2014. Acute phase proteins and their use in the diagnosis of diseases in ruminants: A review. Vet. Med. (Praha) 59:163-180.

Tothova, C., V. Nagyova, and G. Kovac. 2015. Changes in the concentrations of acute phase proteins in calves during the first month of life. Acta Vet. (Beogr.) 65:260-270.

von Keyserlingk, M. A., J. Rushen, A. M. de Passille, and D. M. Weary. 2009. Invited review: The welfare of dairy cattle-Key concepts and the role of science. J. Dairy Sci. 92:4101-4111. https:// doi.org/10.3168/jds.2009-2326.

Weaver, D. M., J. W. Tyler, D. C. VanMetre, D. E. Hostetler, and G. M. Barrington. 2000. Passive transfer of colostral immunoglobulins in calves. J. Vet. Intern. Med. 14:569-577. 